of the worker is longer and has a reflected occipital margin which is lacking in pubiventris and angusta.

The observations of Mr. Gaste and Dr. von Ihering throw light on one of the methods of ant dispersal. Of course, the establishment of a species of ant on an island does not require the conveyance of a whole colony as in this instance, since a single fecundated female enclosed in a vegetable cavity might, if transported in a similar manner, suffice for the establishment of a species.

\title{
ON THE TYMPANUM OF CERTAIN LEPIDOPTERA.
}

\section{By William T. M. Forbes, Ithaca, N. Y.}

At the base of the abdomen in many Lepidoptera there is a curious and complex organ, which has been referred to but rarely in the literature, and which is known, in the Geometridæ, at least, as the tympanum. So far as I have discovered, its function is unknown, but its location and general structure justify the guess that it is the resonator for an auditory organ, corresponding to the well-known one in the Hemiptera. It should prove an interesting problem for the histologist and physiologist. The present article will not consider its function, but will outline its structure in the principal families of Macrolepidoptera, and offer a couple of suggestions as to their relationship.

A brief examination shows that there are several analogous, but not homologous organs of this type in the various families, indicating parallel lines of descent from a form that presumably had neither, but may have possessed a wholly internal sense-organ,-which served as a stimulus to their forma-

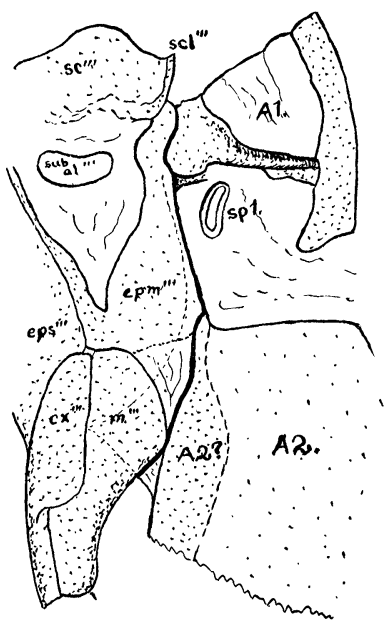

Fig. 1. Side view of metathorax and base of abdomen of Apatelodes torrefacta (Eupterotidæ), showing primitive macrolepidopterous arrangement of sclerities. 
tion,-in connection with the first spiracle. The first type of tympanum is that more or less familiar in the Geometridæ, which is used by Prout (Genera Insectorum, fasc. 103) as the most. fundamental distinguishing character of that family. This appears superficially as a simple hollow balloon located immediately below the spiracle, opening to the exterior in the fold that normally exists in the sclerite of the abdomen facing the hind coxa. It is usually more or less ellipsoidal, and opens conspicuously on the side, forward and outward. In many cases the two tympana are so large as to be separated from each other only by membrane, and look like a pinhole clear through the moth,-as is very conspicuous in Eudule and many Acidaliinæ (Sterrhidæ). In the Ennominæ the organ is smaller and less conspicuous externally, but entirely of the same character, and it exists even in the lower Enochrominæ (Monocteniidæ). In this type the spiracle lies on the upper edge of the organ, and the dorsal part of the segment is normal.

Internally (Fig. 6) the structure is seen to be somewhat more complex. The tympanum itself may be compared roughly to a kettle-drum with edges curving inward strongly to meet the edge of the membranous area that represents the head, and faces forward. (It has been turned back in the figure to show the structures between it and the thorax.) Running almost across this head there is a tapering chitinous tongue, lying in the membrane, to the tip of which are attached a couple of muscles, the soft fleshy connection with the nerve (B), which histological study, is likely to prove the end-organ itself, and a variety of air-sacs and fine tracheæ. In fact the whole organ is enveloped in a system of airsacs, which have mostly been removed in the specimen figured. The external opening of the apparatus is on the side that lies against the body-wall,- - as if a large hole had been cut in the side of the kettle. The nerve-supply appears to be from the anterior segmental nerve of the first segment of the abdomen, which runs back from the ganglion, which is fused with the metathoracic one. This nerve runs past the tympanum anteriorly, and then over the spiracle and up to supply the dorsal musculature, etc. The part of it between the tympanum and spiracle is surrounded by large airsacs, which connect directly with the spiracle.

The European genus Cimelia is generally placed in the Geomet- 


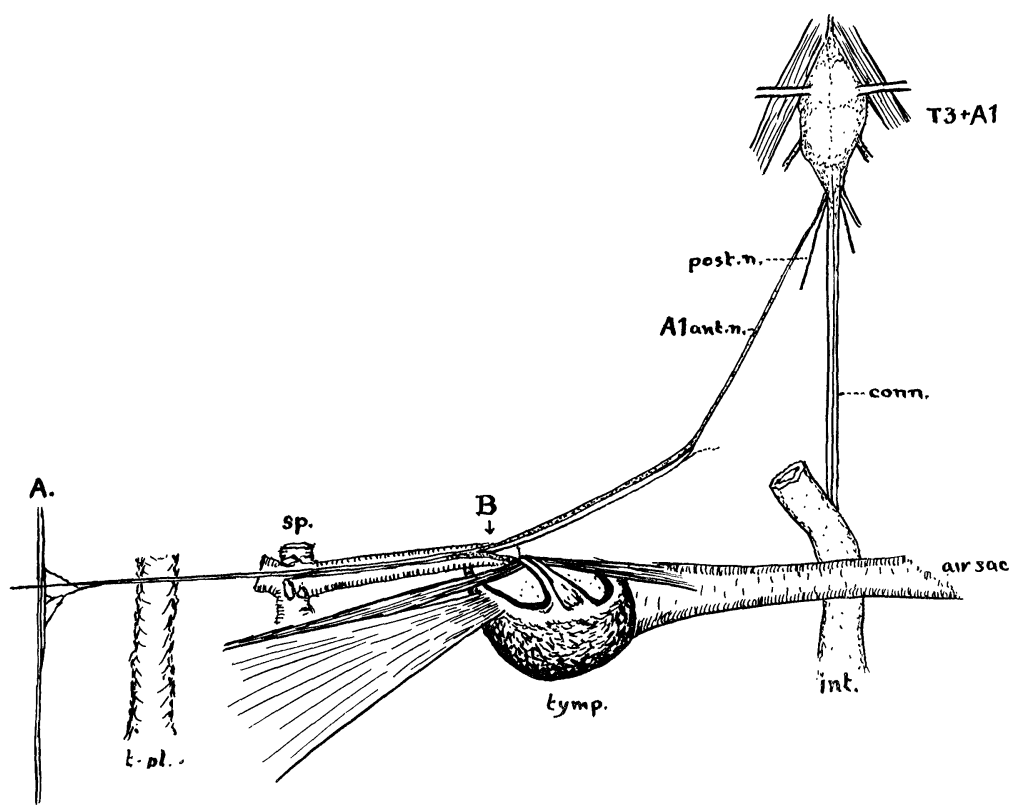

Fig. 6. Tympanum with its principal muscles and nerve connections, of the Geometridæ (drawn from Biston ursaria and Phigalia titea). Only two of the numerous air-sacs are indicated, the one lying ventrad of the nerve, and along which the nerve runs from the tympanum to the spiracle, and the large double one connecting the tympana. The latter appears ventral in the dissection, which was opened out on the middorsal line, but in fact lies above the digestive system. When the dissection is first opened it is normally filled with air and may be the most conspicuous object in the field.

ridæ, but appears to be omitted in Prout's consideration of the Enochrominæ (Genera Insectorum, fasc. 104). A superficial study of the single dry specimen available shows that there is no true tympanum, either of Geometrid or any other type, but there is a slight thickened bar that may represent the bar across the drum-head of the tympanum, lying in the membrane of the ventral surface. There is no definite suggestion of Notodontid structure; and I believe that the genus represents a new family type, leading up to the Geometridæ from something intermediate between the Dioptidæ and Notodontidæ,- - probably direct from the unknown Geometrid-Bombycid ancestral form. There seems to be nothing in venation or mouth-parts to contradict this reference. 
For the normal, and primitive condition in the Lepidoptera (except the very lowest Tineoids and Jugatæ), we may take Apatelodes, a somewhat isolated genus of the Bombycid stem (Fig. 1). Here the metathorax is moderately developed, and there are no specializations which do not occur all the way from the Cossidæ to the Saturniidæ. The scutum and scutellum are normal, the cord connecting the scutellum with the inner margin of the wing is somewhat wavy, but forms no distinct lobe, the epimeron is $\mathrm{V}$-shaped as in the mesothorax, and though too lightly chitinized to be quite sure of its boundaries shows no sculpturing except a slight articular surface where it meets the tergopleural line of the abdomen. The postscutellum is not sharply set off from it, and the entire structure is essentially as in the mesothorax. The first segment of the abdomen is, as usual in Lepidoptera and related insects, largely membranous; the tergum is a rectangle of membrane, enclosed in an anterior band which articulates subdorsally with the thorax, a posterior band, extended well down on the sides, but not reaching the ventral region, and a pair of heavily chitinized lateral grooves;- the latter seem to represent the tergopleural suture, so that the narrow edge of chitin below them should be considered the pleurite. The front end of this groove runs to a shallow pocket between thorax and abdomen. The lateral region is wholly membrane, containing a normal spiracle. Ventrally the first two segments are not distinguished, and are heavily chitinized only in front where they lie against, and are

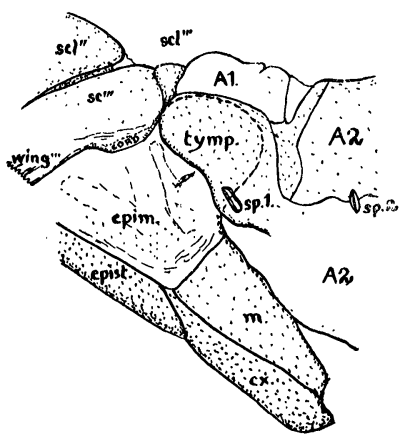

Fig. 2. Same view of Hemerocampa leucostigma (Liparidæ), showing second type of tympanum. slightly grooved by, the posterior coxæ. The external modification to form the first or Geometrid tympanum is merely the enlargement of the coxal groove into an ample cavity, and the distortion of other structures to make room for it.

The second type of tympanum occurs in the Arctiidæ, Lymantriidæ, Syntomidæ, Pericopidæ, etc. (Fig. 2.) In this the thorax is undisturbed, though in the forms I have studied there is the usual lack of definiteness of the epimeron; the abdomen dor- 
sally and ventrally is as before, but in the pleural region above the spiracle there has developed a bulla exactly like that of the Geometridæ externally, but instantly distinguished from it by the fact the spiracle lies on its lower edge. A cursory examination suggests that it has developed out of the remaining rudiments of pleurites. The thorax shows more or less trace of the curious modification described for the Noctuidx, but the venter of the abdomen is typical.

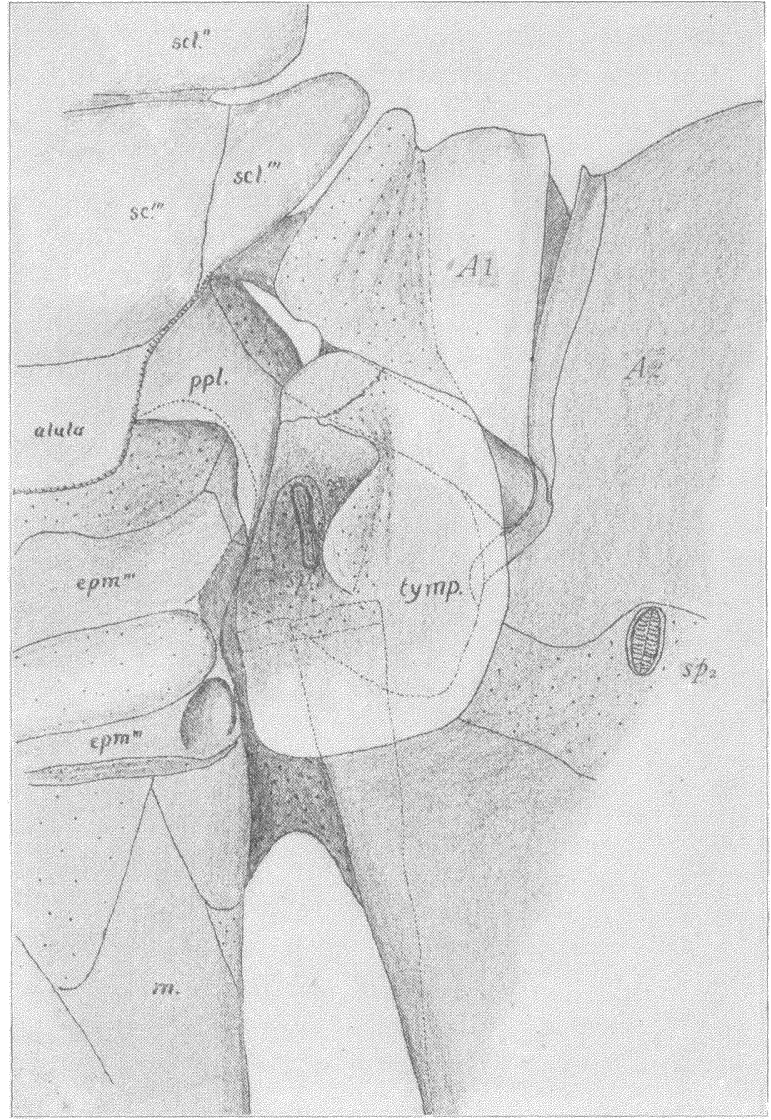

Fig. 3. Same view of Catocala parta, showing third, or usual Noctuid type of tympanum. The cover, or alula of the hind wing is drawn forward, and the posterior edge is turned back to expose the spiracle and structures within the tympanum. 
The third, or Noctuid type, is perhaps the most interesting of all, being at once the most complex, and that occurring in the largest family. (Fig. 3.) Here there is no simple rounded bulla, either subdorsal or subventral, but the whole spiracular region is deeply excavated, the excavation including the posterior region of the thorax as well. This cavity in the more typical case is roofed over by the alula of the hind wing, which is largely developed, especially in such Quadrifidæ as Catocala and the Euteliinæ, and is enclosed behind by a large flap, developed behind the spiracle. It seems to be the same pleurite that has formed this and the bullæ of the Arctioids, but the development has been behind, not above the spiracle, and is of a wholly different character, as the figure shows. Another interesting development is a deep fovea in the parapleural region of the thorax, across which the suture between postscutellum and epimeron may sometimes be traced. In this series the epimeron, often heavily chitinized, tends strongly to break up, and to develop more complex sculpturing, as is notable in Catocala. Alypia and the Notodontidæ (Fig. 5) show interesting variants of this type. In the latter the lateral cavity is present, but slightly developed, and the alula is rudimentary, not covering

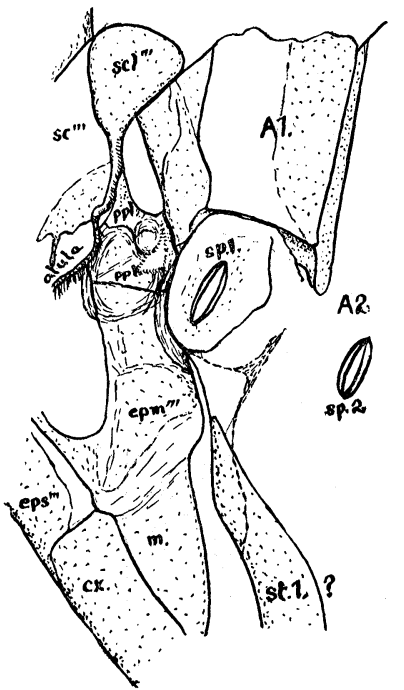

Fig. 5. Same view of Datana ministra. it, the lateral flap behind the spiracle is also absent, though the material from which it forms is indicated as a chitinized area about the spiracle that already tends to overgrow the lateral groove. The parapleural fovea is well marked, however, and already undercuts a portion of the parapleura, which makes a stiff and solid connection with the abdomen (partly broken in the figure). This type could well represent the point of origin of the Noctuid one, but is wholly unlike the simple structure of Apatelodes. In Alypia (Fig. 4) we have a second rather simple modification. The parapleural fovea is well marked, but the region about the spiracle is reduced, without any spe- 
cial sclerites, and in this case the hollow area which normally exists dorsally between thorax and abdomen is very much enlarged, extending back into the second segment, as a thinwalled balloon. In all variants of type three this fold seems much better developed than in the primitive condition.

As to the evolution of these forms I have little doubt that I am correct as to the primitive condition, since it occurs generally in both Micro- and Macrolepidoptera; from it I should derive type three (in its simpler Notodontid subtype) directly, and from that the more specialized subtypes and type two. Type one seems, however, independent. Working this out as a genealogy we will have a first

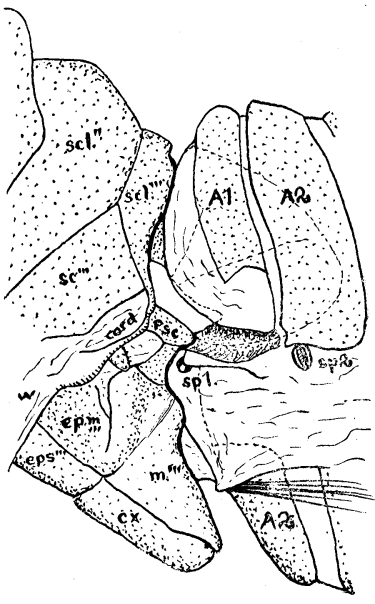

Fig. 4. Same view of Alypia octomaculata (Agaristidæ). The internal expansion of the fold between thorax and abdomen is indicated by the dotted lines. A strong suggestion of this structure occurs in some Noctuidæ. dichotomy between the primitive condition (plus type one) and types two plus three. This corresponds (so far as I recall, exactly) with the division between upright and flat egg, and between the caterpillars with hooks in a single length and those alternately of two lengths, and in those two particulars would dispose of the anomalous position of the Notodontidæ (excluding Apatelodes). It would leave, however, the Notodontidæ as a solitary trifid family in a mass of Quadrifidæ, and would similarly maroon the Lasiocampidæ in a wilderness of trifidæ. Possibly the importance of the position of $\mathbf{M}^{2}$ in the fore wing is less than it has been considered. Already we give little weight to it in the hind wing, and in certain Hydriomenid Geometridæ, such as Eudule.

\section{Families Examined.}

\section{Primitive type.}

Microlepidoptera.

Cossidæ.

Eucleidæ, etc.

Eupterotidæ (Apatelodes).
Bombycidæ.

Saturniidæ.

Sphingidæ.

Lasiocampidæ. 
Type 1 (subventral tympanum). Pericopidæ.

Geometridæ only.

Type 2 (subdorsal bulla).

Lymantriidæ.

Arctiidæ.

Nolidæ

Syntomidæ.
Herminiini and Epizeuxis of the Noctuidæ.

Type 3 (parapleural fovea.)

Notodontidæ.

Noctuidæ.

Agaristidæ.

It should be noted that Brues and Melander, in their key to the families of Lepidoptera erroneously refer to this organ in the Pericopidæ and Geometridæ, as the spiracle; it is perfectly distinct from the spiracle, lying above it in the former, and below in the latter case. So far as I know the spiracle itself is always small and normal, and varies very little in position. It should be noted, however, that the "tympanic opening" of the Dioptidæ (Psyche, XXI, 59, alternative 32) is not homologous with thatof the Geometridæ, but is the rudimentary structure noted in Apatelodes, and which becomes enlarged in the Agaristidæ. In the case of the Pericopidæ (alternative 48) the separation from the Arctiidæ is slender, while the majority of Noctuidæ of course completely lack the bulla. The key would really be cleared up by transferring Haploa to the Pericopidæ, where it would not be as wholly out of place as one might think. The Pericopidæ certainly belong here rather than in the neighborhood of the Notodontidæ or Bombycidæ.

\section{Summary and Conclusions.}

A study of the base of the abdomen in certain Lepidoptera suggests:

1. The Notodontidæ are better placed near the Noctuidæ than near the Geometridæ and Bombycidæ.

2. Apatelodes is not Notodontid, but may be Eupterotid, agreeing in general with the Bombycid series.

3. The Lymantriidæ, Arctiidæ, Nolidæ, Pericopidæ and Syntomidæ are undoubted close relatives, agreeing in a unique specialization.

4. The Noctuidæ, Agaristidæ and Notodontidæ are similarly 
grouped, and no reason has developed to separate them widely from the preceding group.

5. The Bombycidæ, Lasiocampidæ, Saturniidæ, Sphingidæ, Apatelodes, and their relatives also form a distinct group, but as they are associated by the absence of specializations in the structures studied, they may be justly divided up on other characters.

6. The tympanic bulla of the Geometridæ is not homologous with that of the Arctiidæ, etc., being developed on the opposite side of the spiracle.

7. A new subfamily, Cimeliino, is needed for the genus Cimelia, based mainly on the following characters: Tympanum absent; Sc of hind wing not angulate at base, without a brace connecting it with the base of the frenulum, closely parallel to $\mathbf{R}$ to a point well beyond the end of the cell. Structure otherwise as in the lowest Geometridæ (Wnochrominæ).

Supplementary Note: Since writing this article, the Dioptidæ, Thyatiridæ, and Drepanidæ have been examined. The Dioptidæ show no tympanum of any kind and will make a first exception to the rule that uniordinal hooks on the prolegs are coordinated with a tympanum of Arctiid or Noctuid type. The egg is described as spherical, and so may be of either type. In the Thyatiridæ and Drepanidæ there is a new type of tympanum; the tergopleural suture is modified into a large cavity, opening backward, which lies beneath the spiracle, and there is a large double chitinized structure subventrally which does not open to the exterior unless it communicates with this tergopleural opening. The structure is so complex, and so similar in the two families as to make their association almost certain, especially as the larval and venational characters are rather similar.

Explanation of Figures.

A = Lower edge of subdorsal muscle with nerve-supply.

$\mathrm{A}^{1}, \mathrm{~A}^{2}=$ First and second segments of abdomen.

$\mathrm{A}^{1}$ ant. $\mathrm{n} .=$ Anterior nerve trunk of first segment of abdomen.

$\mathrm{B}=$ Supposed sensory end organ of tympanum.

conn.$=$ Connective .

$\mathrm{cx} .=$ Coxa.

epm. $=$ Epimeron (of metathorax).

eps. $=$ Episternum (of metathorax) . 
int. $=$ Portion of digestive system .

$\mathrm{m} .=$ Meron of hind leg.

post. $n .=$ Posterior nerve trunk of first segment of abdomen .

ppl., psc. $=$ Parapleura, or exposed lateral end of postscutellum.

sc $^{\prime \prime}$, sc $^{\prime \prime \prime}$. = Scuta of meso-, and metathorax.

$\mathrm{scl}^{\prime \prime} ., \mathrm{scl}^{\prime \prime \prime}$. = Scutella of meso-, and metathorax.

$\mathrm{sp}^{1} ., \mathrm{sp}^{2} .=$ First and second abdominal spiracles.

subal. = Subalar sclerite of metathorax.

tymp. $=$ Tympanum.

1. Side view of metathorax and base of abdomen of Apatelodes torrefacta (Eupterotidæ), showing primitive macrolepidopterous arrangement of sclerities.

2. Same view of Hemerocampa leucostigma (Liparidæ), showing. second type of tympanum.

3. Same view of Catocala parta, showing third, or usual Noctuid type of tympanum. The cover, or alula of the hind wing is drawn forward, and the posterior edge is turned back to expose the spiracle and structures within the tympanum.

4. Same view of Alypia octomaculata (Agaristidæ). The internal expansion of the fold between thorax and abdomen is indicated by the dotted lines. A strong suggestion of this structure occurs in some Noctuidæ.

5. Same view of Datana ministra.

6. Tympanum with its principal muscles and nerve connections, of the Geometridæ (drawn from Biston ursaria and Phigalia titea). Only two of the numerous air-sacs are indicated, the one lying ventrad of the nerve, and along which the nerve runs from the tympanum to the spiracle, and the large double one connecting the tympana. The latter appears ventral in the dissection, which was opened out on the middorsal line, but in fact lies above the digestive system. When the dissection is first opened it is normally filled with air and may be the most conspicuous object in the field. 

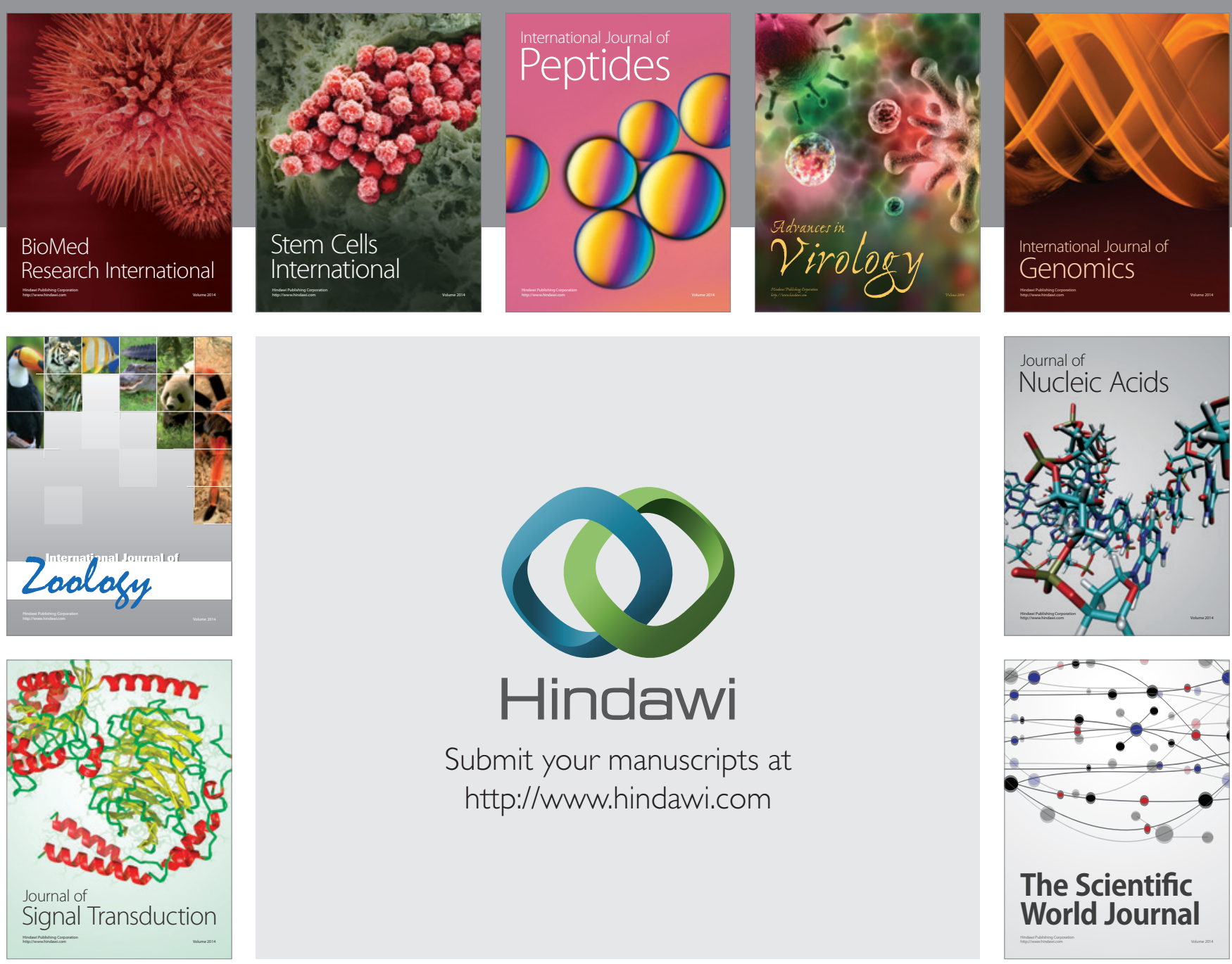

Submit your manuscripts at

http://www.hindawi.com
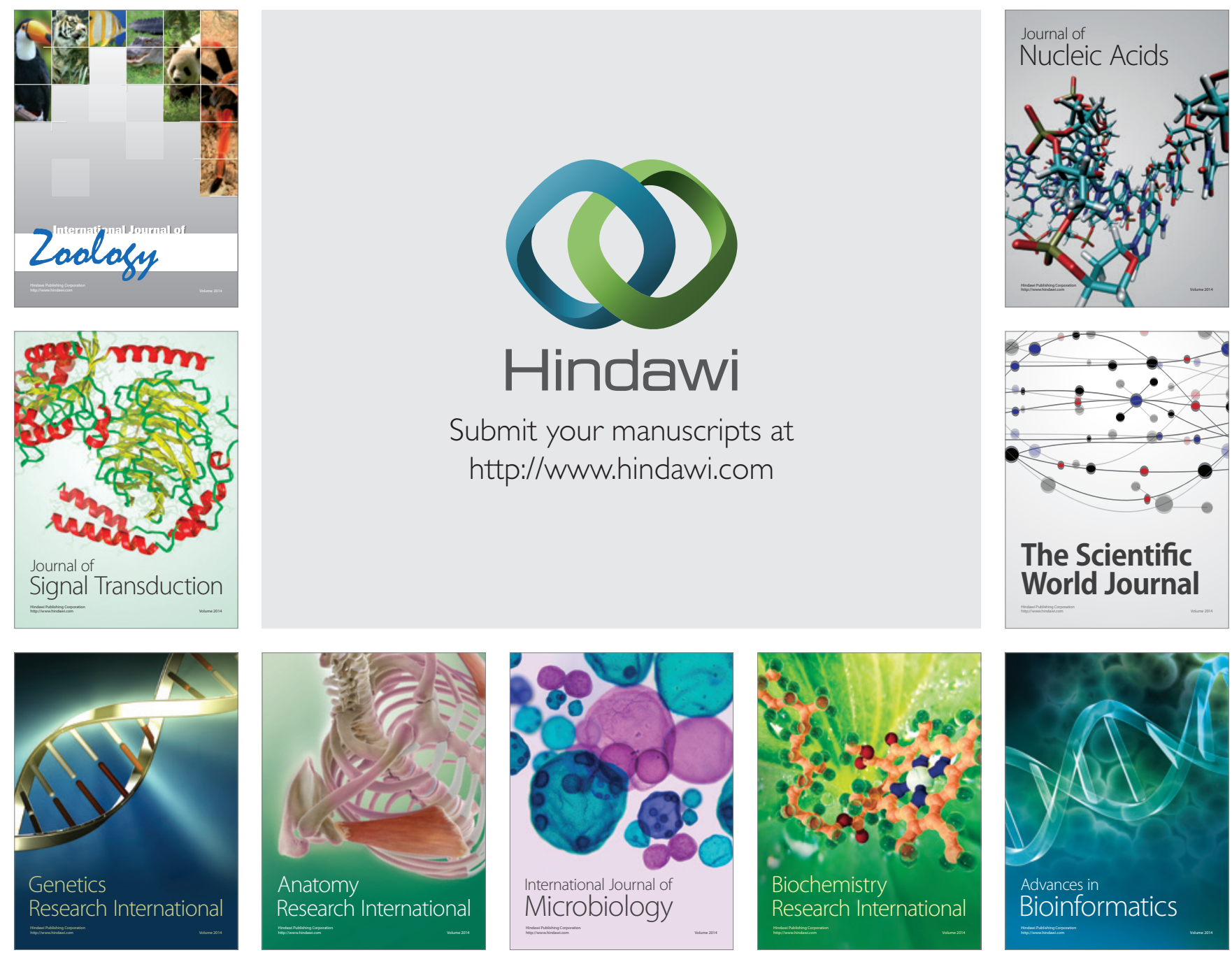

The Scientific World Journal
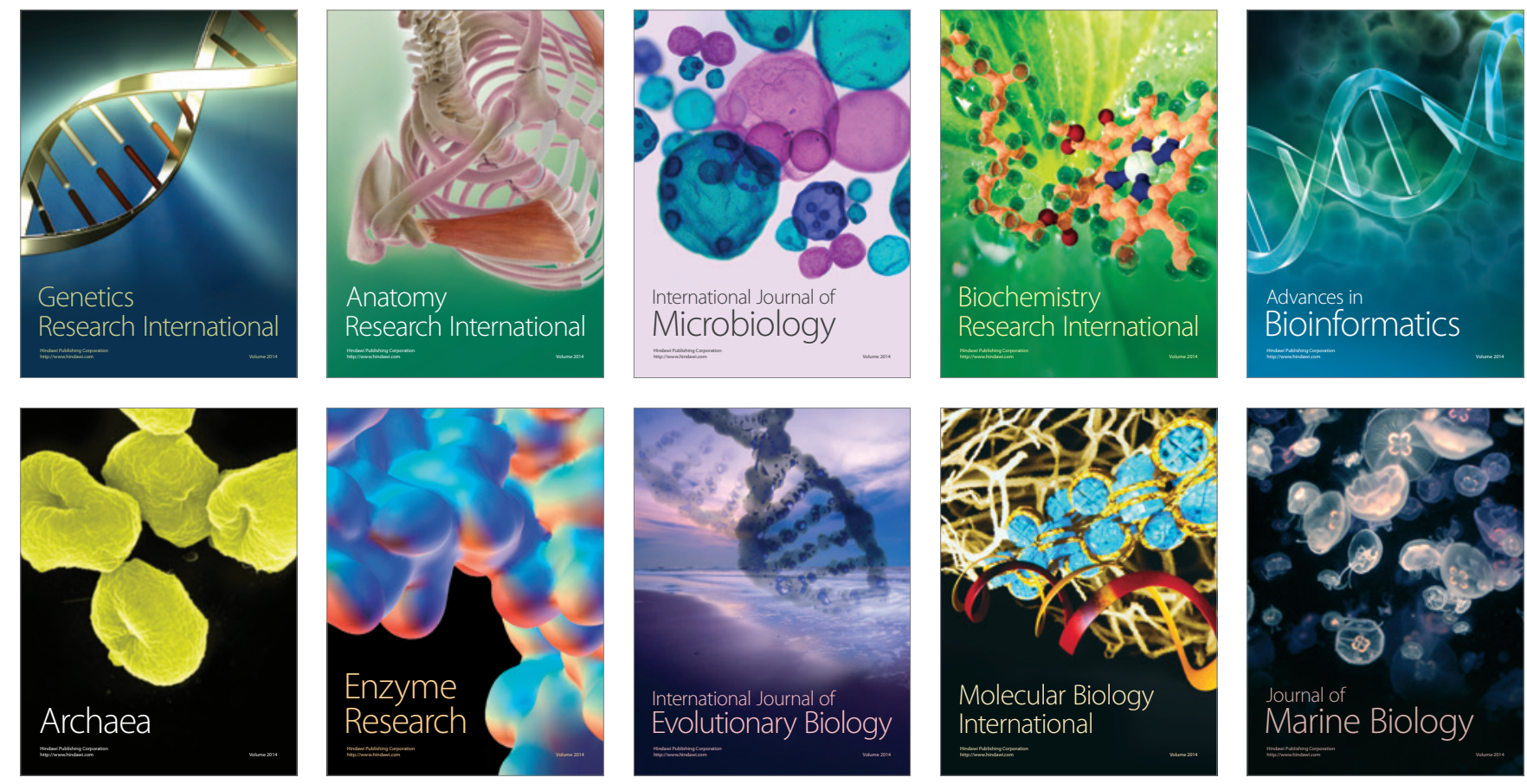